\title{
COMMUNITY PERCEPTION AND PARTICIPATION IN PRESERVING LEBAKMUNCANG TOURISM VILLAGE (THROUGH ALTERATION OF LOCAL RESIDENT'S HOMES BECOME A HOMESTAY)
}

\author{
Lu'luwatin Rosdiana Aprilia \\ Hospitality Programme \\ Akademi Pariwisata NHI \\ Bandung, Indonesia \\ luluwatinrosdianaaprilia@gmail.com
}

\author{
Sara Rabasari \\ Hospitality Programme \\ Akademi Pariwisata NHI \\ Bandung, Indonesia \\ sara.rabasari@gmail.com
}

\begin{abstract}
The objective of this study was to analyze community perceptions and participation in the preservation of Lebak muncang Tourism Village through the diversion ofresidential houses to homestays. The implementation of this research is based on a descriptive research method with a sample of respondents is the Lebak muncang community whose home is used as a Homestay. The results of this study indicate that public perceptions of homestay products from the diversion of residences point of view is more than half of the population are in good category, but perceptions related to internal and external factors of respondents are in the low category because most respondents still have a low level of knowledge that affects his views and thoughts, then the role of the government / community leaders and facilities and infrastructure that are very low results make a reasonable situation when the public perception of homestay products is very low and lacks knowledge. Community participation from the direct and indirect perception, indicate the results of the indirect study participation is considered low, participation should function to advance the Lebakmuncang tourism village by show their willingness to change his house into a homestay that is in accordance with applicable standards and able to develop it and always participate either directly or indirectly.
\end{abstract}

However, it needs to be supported by the role of figures /government in achieving common goals.

Keywords-Community Perception, Community Participation, Homestay, Tourism Village

\section{INTRODUCTION}

In the leadership of President Joko Widodo (2014-2019), the tourism sector is a prority sector. In the work program of resident Jokowi called Nawacita. At present the development paradigm of national tourism destinations leads to development a destination that aims to increase the unity and integrity of the nation, development community-based, poverty alleviation and sustainable use creating a competitive estination, encouraging regional development and empowerment the community. Tourism development focuses on development based community, tourism development based on the community is called Community Based Tourism. One tourism program carried out with an approach Community based is a rural tourism. According to Pariwisata Inti Rakyat defining a rural tourism as a rural area that reflects authenticity rural both from socio-economic life, social culture, customs, daily life, has a building architecture and a typical village spatial structure, or economic activity that is unique and interesting and has the potential to develop various components tourism, for example: attractions, accommodations, food and beverage, and other touristneeds.[1]

One of the villages from several villages that are used as rural tourism is the village Lebak muncang. Lebak muncang village is populated by people from Sundanese background with Islam as the main religion. One of the Lebak muncang village cultures is to go to the top of the hill to hang out with the villagers as a form of their gratitude during the harvest season arrives or during certain occasions. Majority of this village livelihoods is lived as a farmers and livestock breeders. According to the Bandung Regency Regent's Decree with Number 556.42 / Kep.71Dispopar / 2011 concerning the Determination of Tourism Villages in the Region Bandung Regency, there are 10 villages designated as rural tourism according to the potential of each village.[2]

Lebak muncang Village has an area of $802.26 \mathrm{Ha}$ and tourists can stay for a few days in resident's homes and following their routine activities in the village. To make tourists able to learn about the existing local culture, lifestyle and industrial economy, then rural tourism of Lebak muncang needs accommodation that can attract tourists to spend more time in the village. Therefore, the people of Lebak muncang is developing a homestay with the concept of life experience of local people with this homestay, visitors can spent the night or two to have intense interaction with local communities. Since 2014, some people begin to start a business from converting their home into homestay. But in reality, rural tourism of Lebakmuncang who do not have visitors in large numbers, especially those who will spend the night, hampering the development of the tourist village. This also has the least impact visitors who use homestay services, except certain groups is using rural tourism of Lebakmuncang for certain events. Whereas a rural tourism of Lebakmuncang is 
based on data from the Tourism Office of Bandung Regency crowned as one of the dependable rural tourism. Based on observations and initial interview with several community leaders and several tourists who have ever been visiting and staying at Lebakmuncang tourism village, the authors indicate several aspects related to the lack of development of the rural tourism, some of them is the person in charge or the working group is difficult to contact by anyone who wants to know information about the Rural tourism of Lebakmuncang that causes potential tourists reluctant to go to Lebakmuncang because of the first impression at the beginning of information seeking is no response, then no sign or interesting advertisement as a promotion Rural tourism of Lebakmuncang which causes socialization of prospective tourists still very less. Economically there are a lot of land that can be used by local residents for businesses that one of them is his own home, a house that can be used to stay and feel the life of the Lebakmuncang community directly called homestay.

This fact raises many questions for researchers about how perception and community involvement regarding homestay development at Rural tourism of Lebakmuncang as a form of participation in preserving the rural tourism of Lebakmuncang. Based on this description, then this research has the following problem formulation: 1) How is community perception about homestay products from the settlement of residential homes?; 2) How is community participation in homestay development in Lebakmuncang village?; and 3) How is the form of community participation in Lebakmuncang village through the conversion from houses into a homestay to preserve Lebakmuncang Tourism Village?

Based on the formulation of the problem above, the purpose of this study was to find out: 1) Public perception about homestay products from the settlement of residential homes; 2) Community participation in homestay development in Lebakmuncang village; 3) Perception the community regarding the form of community participation in the village of Lebakmuncang in managing homestay to preserve Lebakmuncang Tourism Village.

\section{LITERATURE AND RESEARCH METHODOLOGY}

\section{A. Tourism Village Preservation}

The initial concept of conservation was preserving, namely effort conserving and protecting while utilizing resources somewhere with adaptation towards new functions, without eliminating the meaning of cultural life. [3] Then, Community Based Tourism as tourism that realizes it will cultural and natural potential where this form of tourism is managed and owned by the community locally aimed at helping tourists to learn about the lives of local people.[4] This definition provides an understanding that Community Based Tourism is a form of tourism that involves local communities in its management with the aim of provide benefits to local communities while introducing the lives of local communities to tourists who come to visit.

\section{B. Alteration of Local Resident's Home to Homestay}

Alteration is a word derived from English, namely alteration, which means change. Changes according to Pasmore, state that change can happen to us and around us, sometimes even we don't realize that this is happening.[5]

Alteration means that we must change in how to do or think about something, which can be expensive and difficult. One of the type of accommodation that is quite attractive is homestay. Different with the guest house, Homestay is a type of accommodation that is quite popular in urban areas as well rural areas in Indonesia, namely using private residences as tourist attractions stay overnight. Generally homestays provide room division service along with food and drinks. One of the advantages of homestays is that tourists can get the opportunity to get to know the owner's family. They can also know more about nature and culture around especially if the homeowner has a lot of knowledge about it. Basically, the definition of HouseHotel is the same with homestays. According to ASEAN Tourism Standards (2007), homestay is a form of accommodation that uses a local home, providing opportunities for guests / tourists to live the family's daily life or community as well as a tourist attraction.

\section{Perception and Community Participation}

Perception generated by each person can be different for the same stimuli. The differences in perceptions can occur because there are five factors that influence perception formation. These factors are culture, socioeconomic status, age, religion, and interaction between gender roles, village / city, and ethnicity.[6] Community perception in context changes in people's homes to homestays are public views about the importance of accommodation in preserving the rural tourism of Lebakmuncang which starts from the change in the function of local resident's home becomes a homestay that is a characteristic of a person rural tourism. Community perception is one of the determinants of the level of community participation because perception is a psychological process that is dependent of each individual which functions to shape attitudes and determine decisions to act. If community perception in converting local resident's home to become a homestay is good, then participation the community in the preservation of tourism villages will increase. The community participation is often interpreted as participation, involvement and similarity of community members in a particular activity directly or indirectly, as idea, policy formulation, implementation program and evaluation. [7] Direct participation means that members of the community participate energy assistance in activities carried out, while indirect participation can in the form of donations of thought, funding and material needed.

\section{Research Methodology}

This study uses a descriptive research method, namely research that seeks describe or describe the phenomenon or relationship between the phenomena under study systematically, factually and accurately. [8] The purpose of the descriptive method is to collect actual data and information in detail that can describe the symptoms social community. By using descriptive methods, researchers will be able to describe it how community involvement in the preservation of the Rural tourism of Lebakmuncang throughAlteration of local resident's houses into homestays. 


\section{RESULT AND DISCUSSION}

1. Result of Research

Internal Factors of Individual Respondents Research aimed at finding an illustration of community perceptions and participation in the preserving the rural tourism of Lebak muncang through the change of the local people's house into homestays that involve a description of people's thinking. Characteristics of the community who became respondent in this study consists from educational and working background.

TABLE 1.

\section{RESPONDENTS' EDUCATIONAL BACKGROUND}

\begin{tabular}{|c|c|c|c|}
\hline No & Education & $\mathbf{f}$ & $\%$ \\
\hline 1 & Elementary school & 18 & 26.9 \\
\hline 2 & Junior high school & 21 & 31.3 \\
\hline 3 & High school & 22 & 32.8 \\
\hline 4 & $\begin{array}{c}\text { Under Graduate/Post } \\
\text { Graduate }\end{array}$ & 6 & 9.0 \\
\hline \multicolumn{2}{|r|}{ Total } & 67 & 100.0 \\
\hline
\end{tabular}

Source: Processed Author Data, 2018

The community here generally has the most background being high school graduates as many as 22 people $(32.8 \%)$. These data illustrate that in the village of Lebak muncang, the average has followed the government's invitation to the 9-year compulsory education program the second most data followed by junior high school graduates around $31 \%$, after that the third is elementary school graduates because there are still many who do not continue school, especially the oldest. But in the tourist village Lebak muncang there are also graduates around $9 \%$ Of the 44 respondents who work on average, 21 people have a jobs as farm workers $(47.7 \%)$. Came second is a job as a private employee with 5 people $(11.36 \%)$. The third majority is working as a factory workers with 4 people $(9.09 \%)$ followed by respondents who work as laborers and and convenient store employee with 3 people each $(6.28 \%)$. Then the respondent is people who work as a civil servants, teachers and factory employees respectively with 2 people $(4.55 \%)$ and lastly the least profession is as a farmer with 1 person $(2.27 \%)$.

TABLE 2. CHARACTERISTICS OF RESPONDENTS' WORK STATUS

\begin{tabular}{|c|c|c|c|}
\hline No & Working Status & $\mathbf{f}$ & $\mathbf{\%}$ \\
\hline 1 & Working & 44 & 65,7 \\
\hline 2 & Doesn't Work & 23 & 34,3 \\
\hline \multicolumn{2}{|c|}{ Total } & 67 & 100.0 \\
\hline
\end{tabular}

Source: Processed Author Data, 2018
Distribution of respondent job data can be seen in Figure 1 below:

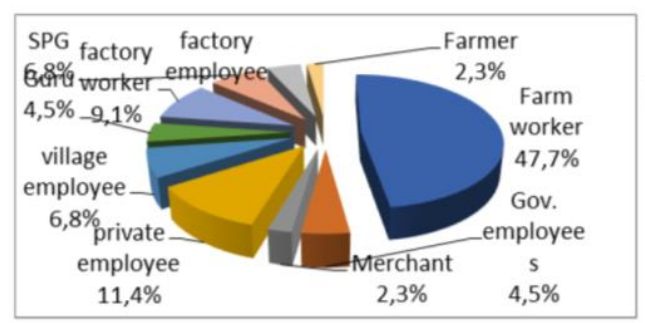

Fig 1. Diagram of Percentage of Respondent's Job Distribution (Source: Processed Author Data, 2018)

Knowledge of Respondents Of each question asked, respondents who have understood do not reach a percentage 50\%upwards. It can be seen that as many as $76.1 \%$ of respondents have understand the benefits of the homestay and which are not included in the benefits of providing services homestay service. As many as $58.2 \%$ of respondents have comprehend the negative and positive impact arising from the homestay. As many as $19.4 \%$ of respondents have find out how homestays are standard, and as many as $14.9 \%$ of respondents have understand the meaning of homestay. Nearly half of the respondents $(65 \%)$ did not know about homestay and how it will be proven in the future with the few who answer about what to do with a good homestay on this question only 3 people $(4.5 \%)$ respondents answered correctly, while the rest were $95.5 \%$ of respondents answered incorrectly. Respondents' knowledge consists of two categories, namely high and low. Data calculation results primary using a questionnaire shows that less than half of the respondents, namely 23 people have a high level of knowledge. But 44 respondents were classified as having low level of knowledge about homestay. Distribution of respondents based on level knowledge about homestay management is presented in Table 3.

TABLE 3. DISTRIBUTION OF RESPONDENTS BASED ON THE LEVEL OF KNOWLEDGE ABOUT HOMESTAY

\begin{tabular}{|c|c|c|}
\hline $\begin{array}{c}\text { Knowledge } \\
\text { Category }\end{array}$ & Total & $\mathbf{( \% )}$ \\
\hline Low & 23 & 35 \\
\hline High & 44 & 65 \\
\hline Total & 67 & 100 \\
\hline
\end{tabular}

Source: Processed Author Data, 2018

Table 3 shows that $65 \%$ of respondents still have a low level of knowledge, while only $23 \%$ have had a high level of knowledge about homestay.

Experience of Respondents

Activities that are directly related to the management of the homestay are cooking for theguests, dancing and singing in Sundanese arts and gamelan, build additional rooms, refit toilets and lavatories, interact directly with travelers, tourists guide both for domestic and foreign tourist, and directly involved in the development of tourist villages. Activity indirectly related to the management of the homestay in the rural tourism istake part in socialization and training on homestay management. There are 
two categories for the respondent's experience, namely low and high. In research there are 4 people with a high level of experience and 63 people with low levels experience in managing homestays. On average they gain experienced only from direct interaction with tourists without having any participation in training / socialization and other things.

External Factors of Individual Respondents Individual external factors in this study are the factors contained in research respondent environment. These factors consist of the role of government / figure community and facilities and infrastructure. The role of government / community leaders in this study measured by giving 9 questions to the respondent about the actions that have been taken carried out by the government/community leaders in developing and supporting governance homestay to preserve rural tourism of Lebak muncang. The action is in the form of counselling, training, encouragement, giving examples, and invitations to solve problems homestay. The role of government / community leaders has two categories, namely high and low the results of which are obtained through the accumulation of 9 questions regarding the role of government / figures the community. The results obtained through the questionnaire show that as much as $39 \%$ Respondents answered that the role of the government/ community leaders in managing homestay classified as high, while the remaining $61 \%$ of respondents answered low. Distribution of respondents based on the description of the role of government / community leaders is presented in Table 4 below:

\section{TABLE 4. DISTRIBUTION OF RESPONDENTS' ANSWERS}

\begin{tabular}{|c|c|c|}
\hline $\begin{array}{c}\text { Role } \\
\text { Category }\end{array}$ & Total & Percentage (\%) \\
\hline Low & 41 & 61 \\
\hline High & 26 & 39 \\
\hline Total & 67 & 100 \\
\hline
\end{tabular}

Source: Processed Author Data, 2018

The table above shows that all respondents consider the role of government / figure people in homestay management are low. Meanwhile, in this study, Infrastructure Facilities is measured by giving respondents 4 questions about their suitability government-built facilities and infrastructure in developing and supporting and also preserving rural tourism through homestay in Lebak Muncang. Results obtained through questionnaires show that as many as $43 \%$ of respondents answered that the facilities and infrastructure were managed Homestay is categorized as adequate, while the remaining $57 \%$ are respondents answer is inadequate. The respondent's distribution is based on an overview of the role of the government / figure community is presented in Table 5.

TABLE 5. DISTRIBUTION OF RESPONDENTS' ANSWERS BASED ON FACILITIES AND INFRASTRUCTURE

\begin{tabular}{|c|c|c|}
\hline $\begin{array}{c}\text { Role } \\
\text { Category }\end{array}$ & Total & Percentage (\%) \\
\hline Low & 29 & 43 \\
\hline High & 38 & 57 \\
\hline Total & 67 & 100 \\
\hline
\end{tabular}

Source: Processed Author Data, 2018
Community Perceptions of Changes in Residential Residents become Homestay Perceptions of changes in residential houses of residents into homestays here are examined by seeing the views of the rural tourism in Lebak muncang residents by assessing changes in function rather than living as a homestay to support the preservation of tourist villages Lebak muncang. Respondents' responses regarding Perception. Based on the results of processing presented in the table above, it can be seen the total score for Perception is 1710. Amount the score is entered to the continuum line.

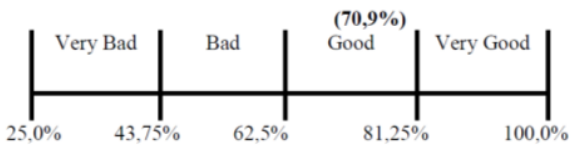

Fig 3. Continuous Participation Line of Community Participation

\section{Discussion}

Community Perception Regarding Homestay Products from Settling Homes Population. Research data on community perceptions regarding Changes in Residential Residence become a Homestay that is obtained from the community response conducted in the tourist village Lebakmuncang related to the Process of Change, Change Activities, and Results from Change. The results of this study shown that more than a half of the public's perceptions on the integration of houses in this population is in a good category, in line with author expectation that the community is accepting their house to be used as a homestay for the tourists with intention to preserving the rural tourism of Lebak muncang but still aware on the fact that their knowledge is still limited.

Community Perception in Homestay Development in Lebak muncang Village Research data regarding public perceptionsregarding homestay development obtained from community responses conducted in the rural tourism of Lebak muncang related to internal and external factors of respondents. Internally respondents have perceptions that are influenced by gender, age, last education, employment status, knowledge and experience of respondents related to respondents. Results research that shows that most respondents (the people of Lebak muncang Village) still have a low level of knowledge that affects the perception of respondents to the homestay products in the village where they live. In accordance with the results of interviews with several communities who were made as respondents one of them (AS) saidthat "da prinsip homestay di dieu mah neng tujuanna tamu tiasa ngendong di salah sawios bumi penduduk". The statement gives understanding that the perception of homestay products here is that tourists can stay in the village Lebakmuncang but their knowledge about the concept of homestay is still limited to a place to stay, even though homestay quality standards should be based on the Permen Parekraf No. 09 of 2014 concerning standard cottage business which is generally a standard homestay business this includes aspects of the product, service and management of the homestay itself. Other than that, The standard of this homestay business is also based on the ASEAN Homestay Standard which is concisely contains two topics, namely for the Village Tourism Working 
Group as the Person who manages the Homestay which includes the homestay product itself, tourism activities, management, location, security and safety, marketing and promotion, and the principle of sustainability. The second is that the Homestay owner covering all aspect of Accommodation (The House, The Bedroom, The Toilet / Bathroom) and Hygiene and Cleanliness (Kitchen, Bedroom \& Toilet; Surrounding Compound; Food Preparation, Environmental Sustainability, and Sociocultural Sustainability). The discussion relating to internal factors of public perception are those which include homestay owners / Homestay Provider who must have certain standards when following the Permen Parekraf's rules and ASEAN standards that the authors suspect that the Lebak muncang community in particular is have not yet understand about the homestay standards. This situation is proven by the results of the study which showed almost more than half of the respondents did not know how homestays that meet the standards are also in line with the results of several observations researchers where there are many homestays there are still many that did not comply with standards and have a toilet that is separated from the house. In addition, the respondent's experience also means thatRespondents have directly felt an activity with their senses. This is very close relation to the notion of perception described by Leavitt (1978), namely perception is an assessment or interpretation of a person from the stimulus captured by the tool the senses. Experience is the result of accumulation of the next learning process influence how someone views an object / event. Average of respondent only experienced direct interaction with tourists without any experience following training / socialization and so on. Furthermore, it affects the perception of the people who do not run the management Homestays according to standards are external factors which consist of government / character roles community and facilities and infrastructure, where the results are so low that it becomes natural why people's perception of homestay products is very low and lacking his knowledge. Based on the explanation above, it can be concluded that public perception in context Homestay products from residential homes are public views about change of his house to be used as a place to stay, which should encourage behavior the community in managing homestay development according to standards and being commercial and preserve the sustainable Lebak muncang tourism village.

Participation of the Lebak muncang Village Community through converting their Homes to become a homestays to preserve Lebak muncang tourism village From the results of research regarding direct and indirect participation of the community preserving the rural tourism of Lebakmuncang was taken from the respondent's responses which included Direct participation (How to manage a Homestay, Level of home decorating initiative, Homestay promotion, persuasive level of tourists, willingness to involved, deep initiative to answer all tourist questions, Involvement in tourist banquets, Involvement in homestay management, involvement in every tourist activity and participation in art activities) while indirect participation includes (take part to provide criticism and suggestions, participate in discussions about homestay management, participate in counselling regarding village tours and homestay development, participating in government housekeeping training and arrangement, and participate in payment of levies). Research results regarding More than half of the direct participation of respondents gave good responses meaning that people are happy to participate directly especially on times when tourists ask directly about the tourist village Lebak muncang, the community will have an initiative to answer, this is in line with the statement expressed by Wibisono (1989) in Alfiandra (2009) that direct participation means community members participate provide energy assistance in activities carried out.

The result is far different from the indirect participation of the community that provides the results of the study were less than half of the respondents gave a bad response. That most striking is the response to the statement participating in counselling village tourism and homestay development, Participating in housekeeping and meditation training where as a result more than $70 \%$ of the people answered they never followed it. This situation is directly proportional to the results of research on public perceptions influenced by external factors, namely the role of government / community leaders show results that the community / respondent assesses the role of the government / community leaders in low homestay management. The government is considered to have less role in driving the community to manage their homestays. Village Working Group join with the staff to always monitors the homestay management activities. Hard effort that's been done by community leaders is what makes people aware that willingness to start managing each homestay comes from within the community itself.

Based on the explanation above, it can be concluded that community participation in the context changes in residential houses into homestays for the sustainability of tourist villages are community views regarding its role as a community and components in advancing the tourist village Lebak muncang is by willingness to change his house into a suitable homestay with applicable standards and able to develop it and always participate both directly or indirectly. However, it still needs to be supported by the role of figures / government to achieve common goals.

\section{CONCLUSION}

Based on the results of the research and discussion that has been prepared by the researcher, it can be concluded that:

- Public perception about homestay products seen from the settlement of homes from more than a half of th epopulation is in good category, this condition is in line with the writer suspecting that the community accepted their house to become a homestay for tourists is to preserve the Lebak muncang tourism village, however apart from that, their knowledge is still low and limited to standard homestay.

- Community perceptions regarding the development of community perception related homestays with respondents' internal and external factors that shouldencourage behaviour in the community in managing homestay development according to standards by being commercial is to preserving the sustainable Rural tourism of Lebakmuncang in fact these two factors are in the low category because mo st respondents (Lebak muncang Village community) still have a low level of knowledge so it influences his views 
and thoughts, then government / community leaders roles and facilities and infrastructure whose results are very low make a reasonable situation when people's perception of the homestay product is very low and lacks knowledge.

- Community participation in the context of changingresidential houses to become homestays for the preservation of tourism villages are the community view regarding his role as a community and a component in advancing the tourism village Lebakmuncang by willingly to change their house into a homestay that complies with applicable standards and able to develop it and always participate both directly and indirectly. However, it needs to be supported by the role of figures / government in achieving common goals together.

The author gives some implications for the results of this study including though the community welcomed the settlement of people's homes to become a homestay, but learned that public knowledge about the homestay product still low and even the perception is limited. Therefore, full support is needed from the government including education and training and also counselling about homestay and tourism villages for all levels of society not only for working groups. One of the most important steps is to invite people to develop and managing Homestay that meets the standards by changing people's perceptions towards homestay itself. Awareness is needed through socialization and regularly monitored in managing and developing homestay. When this can optimally run and influence the preservation of Lebak muncang tourism villages in a sustainable manner. Based on the results of research on community participation in preserving the Rural tourism of Lebak muncang through the settlement of houses to become homestay, the advice that can be given is recommendations for further research, namely: Need to be examined about the comparison of perceptions and community participation between two tourist villages that have management conditions and development different homestay. Then, there is a need for community leaders who can act as a driver to advancing the area. People who are respected by society is a capital for an area to be able to carry out program's participatory development.

\section{ACKNOWLEDGMENT}

This research was supported by NHI Tourism Academy of Bandung. We thank our colleagues from there who provided insight and expertise that greatly assisted the research, although they may not agree with all the interpretations/conclusions of this paper. We thank to Mr. Dadi and Mr. Sulaiman for assistance with particular technique, methodology, and Mr. Donny Yudhono as Director, Mr. Djoko \& Mr. Yayan Sugiarto for comments that greatly improved the manuscript. We would also thank to 3 "anonymous" reviewers for their so-called insights. We are also immensely grateful to all of you for their comments on an earlier version of the manuscript, although any errors are our own and should not tarnish the reputations of these esteemed persons.

\section{REFERENCES}

[1] Pokja Desa Wisata Lebakmuncang. (references)

[2] Surat Keputusan Bupati Kabupaten Bandung dengan Nomor 556.42/Kep.71-Dispopar/2011 tentang Penetapan Desa Wisata Di Wilayah Kabupaten Bandung

[3] Minarti, Ria, dkk. Peran Dinas Pariwisata Kota Semarang Dalam Upaya Melestarikan Gedung Lawang Sewu Sebagai Objek Wisata Peninggalan Belanda Di Kota Semarang Jawa Tengah Tahun 2011 - 2014. Historia Journal, vol 4, No 1 (2016), pp. 29-38

[4] Hadiwijoyo, Suryo Sakti. 2012. Perencanaan Pariwisata Berbasis Masyarakat (SebuahPendekatan Konsep). Graha Ilmu. Yogyakarta.

[5] [5] Wibowo. 2005. Layanan Bimbingan Kelompok dan Konseling Kelompok. Jakarta : Rineka Cipta

[6] Sarwono SW. 1999. Psikologi Sosial Individu dan Teori-Teori Psikologi Sosial. Jakarta (ID): Balai Pustaka.

[7] Alfiandra. 2009. Kajian partisipasi masyarakat yang melakukan pengelolaan persampahan 3R di Kelurahan Ngaliyan dan Kalipancur Kota Semarang [tesis]. Semarang (ID): Universitas Diponegoro. [Internet]. [diunduh 2013 November 9]. Tersedia pada: http://eprints.undip.ac.id/24266/1/ALFIAN DRA .pdf

[8] Kusmayadi. 2004. Satistika Pariwisata Deskriptif. PT. Gramedia Pustaka Utama. Jakarta. 